ACTA MYCOLOGICA

Vol. 44 (2): 185-199

2009
Dedicated to Professor Krystyna Czyżewska

in honour of 40 years of her scientific activity

\title{
Lichens and allied fungi of two Regional Parks in Vilnius area (Lithuania)
}

\author{
JURGA MOTIEJŪNAITE் \\ Laboratory of Mycology, Institute of Botany, Žaliujų ežerų str. 49 \\ LT-08406 Vilnius 21, mikojm@botanika.lt
}

Motiejūnaitė J.: Lichens and allied fungi of two Regional Parks in Vilnius area (Lithuania). Acta Mycol. 44 (2): 185-199, 2009.

Two Regional Parks - Verkiai and Pavilniai are situated in Vilnius city area comprising territories both of the city itself and Vilnius district and are under strong anthropogenic influence. During the present study 172 species of lichens, lichenicolous and saprobic fungi were revealed in Verkiai RP and 92 species - in Pavilniai RP. Three lichen species Absconditella pauxilla, Thelenella pertusariella (in Verkiai RP), Bacidia caligans (in Pavilniai $\mathrm{RP}$ ) and one saprobic fungus - Chaenothecopsis debilis (in Verkiai RP) are reporded for the first time in Lithuania. Seven lichen species of Lithuanian Red Data Book were recorded, all of them only in Verkiai RP; this indicates less strong anthropogenic impact and better conditions for biodiversity in this Park.

Key words: lichens, lichenicolous fungi, protected areas, biodiversity, Lithuania

\section{INTRODUCTION}

Lichens of Vilnius environs, though being closest to the centres of botanical investigations of Lithuania - Vilnius University and Institute of Botany was quite understudied up to present. First data on lichens from Vilnius and environs, albeit very fragmentary, are found already in the first Lithuanian botanical references: B.S. Jundziłł (1811) and J. Jundziłł (1822a, b, c), though in truth not a single territory in Vilnius city or its environs were ever lichenologically detailly studied. This refers to the present areas of two Regional Parks situated in Vilnius city territory: Verkiai and Pavilniai RP. None whatsever lichenological material was tracked for Pavilniai RP, except single specimen of Peltigera rufescens (Weiss) Humb. from WI herbarium cited by Motiejūnaite and Miądlikowska (1998). First data on lichens from Verkiai RP are found in Mowszowicz (1957-1959). In total he indicates 43 lichen species, though it is not clear whether they are from the exact territory of the RP, the locality 
is indicated as Wilno, Werki. Part of this report is dubious, e. g. Opegrapha atra Pers., Bacidia obscurata (Sommerf.) Zahlbr. (Mycobilimbia tetramera), Cladonia glauca Flörke, Ramalina pollinaria (Westr.) Ach., but none of the herbarium specimens has survived to present time and it is impossible to revise them.

During the last 15 years fragmentary data on lichen finds in Verkiai RP (mainly Žalieji ežerai Landscape Preserve) were published by several authors: Balevičius (1992), Kukwa \& Motiejūnaitè (2005), Miądlikowska \& Motiejūnaitè (1994), Motiejūnaite (1999, 2007a), Motiejūnaitė \& Miądlikowska (1998) and Motiejūnaitė \& Prigodina (1999).

This paper presents first detailed study of lichen biota in both Verkiai and Pavilniai regional parks.

\section{STUDY AREA}

Pavilniai Regional Park is situated at the southeastern edge of Vilnius city (Fig. 1). It occupies 2153 ha area, which includes territories of both Vilnius city and Vilnius district $\left(54^{\circ} 39^{\prime}-43^{\prime} \mathrm{N}, 2^{\circ} 19^{\prime}-25^{\prime} \mathrm{E}\right)$. This smallest Regional Park in Lithuania was established in 1992 (since 1984 this was territory of the Nature Park) to protect

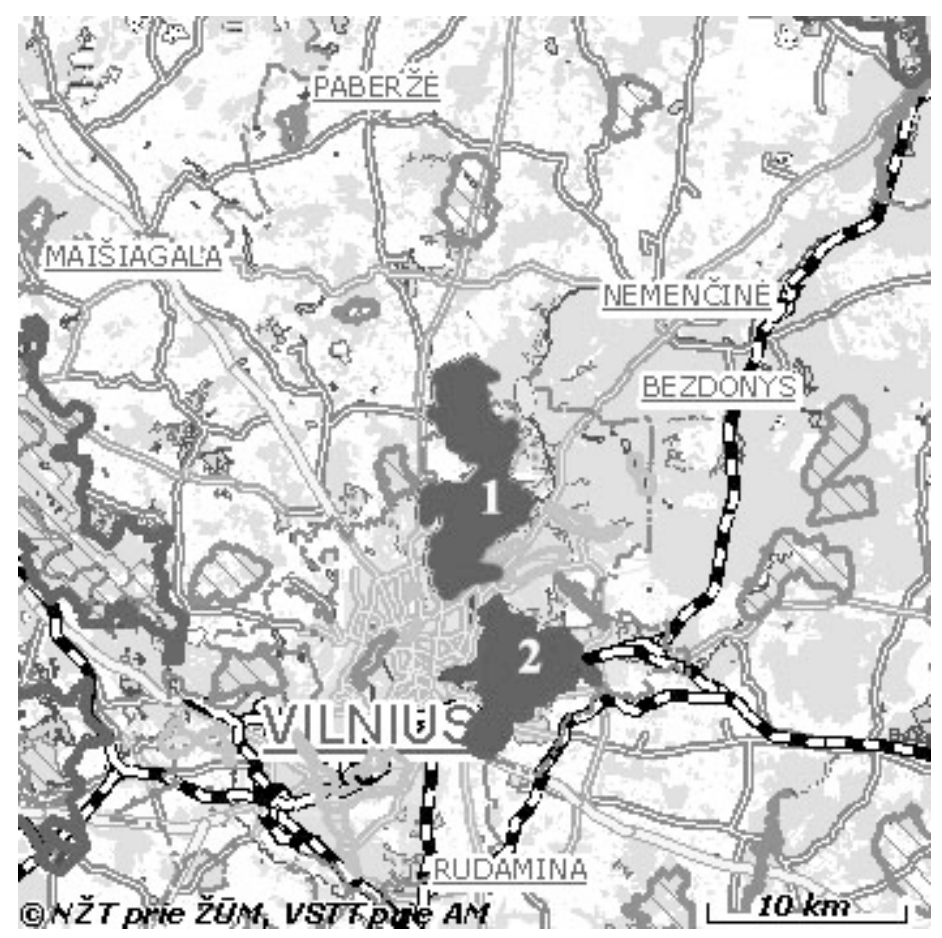

Fig. 1. Location of Verkiai (1) and Pavilniai (2) Regional Parks (map from state cadastre of protected areas: http://stk.vstt.lt, modified). 
landscape of eroded ravine, hill system and valley of Vilnia river. Though part of the Park is Vilnius city, there are still numerous close-to-natural or seminatural forests with large diversity of vascular plants (forest covers $76,5 \%$ of the Park area). 10 Preserves and one Strict Nature Reserve warrant protection of rare plant species and communities as well as landscape formations. Especially valuable is the area of Kalnai Strict Nature Reserve with diverse forest stand communities occupying relief with hills and ravines.

Verkiai Regional Park is situated at the northeastern edge of Vilnius city (Fig. 1), it occupies 2673 ha area, which includes territories of both Vilnius city and Viln-

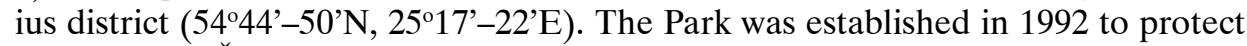
landscape of Žalieji ežerai lakes' complex and valuable cultural complexes of Verkiai, Kalvarijos and Trinapolis. Forest covers $76 \%$ of the Park area. Southern part of the Park comprises mainly cultural objects; meanwhile northern is rich in nature values. Especially valuable is forest-covered hilly area with five glacial lakes, which are called Žalieji ("Green") due to greenish colour of water with high content of carbonates. Calcareous soils, beneficial microclimate and hilly relief ensure existence of exceptionally rich plant diversity (Kirstukas 2004).

Both Regional Parks are under strong anthropogenic influence: some part of both comprises built-up areas, both parks are popular recreation zones for city people. Besides, Pavilniai Park is strongly influenced by the emissions of Vilnius city transport and industrial objects.

\section{MATERIAL AND METHODS}

Lichens and allied fungi were collected in 2006 from the whole territory of Verkiai and Pavilniai Regional Parks. All habitats and substrates were considered. Lichens were identified following routine microscopic techniques; sterile corticolous lichens as well as some specimens of Cladonia genus were identified employing TLC (methodology following Orange et al. 2001). Critical specimens were compared with the identified collections at the herbaria of the Botanical Museum, University of Copenhagen (C) and of the Botanical Museum Berlin-Dahlem (B). Voucher specimens of the study are deposited in the Herbarium of the Institute of Botany (Vilnius) (BILAS).

\section{LIST OF SPECIES}

New species to Lithuania are marked with !, lichenicolous fungi are marked with \#, non-lichenized saprobic fungi are marked with + . Nomenclature basically follows Santesson et al. (2004), also further sources such as Blanco et al. (2004), Lücking et al. (2004), Veldkamp (2004) and others. 


\section{VERKIAI REGIONAL PARK}

:Absconditella pauxilla Vězda \& Vivant - on dead mosses growing at the edge of pine stand; A. lignicola Vězda \& Pišut - on wood of fallen, decaying, barkless trunk of Picea abies.

Acarospora fuscata (Schrad.) Th. Fr.- on a siliceous stone.

\#Acremonium sp. - on primary squamules of Cladonia coniocraea, possibly associated with Nectriopsis parmeliae (for the description and notes see Motiejūnaité (2006)).

Acrocordia gemmata (Ach.) A. Massal. - on trunks of Acer platanoides, Quercus robur and Populus tremula.

Amandinea punctata (Hoffm.) Coppins \& Scheid. - on trunks of Quercus robur and Acer platanoides.

Anaptychia ciliaris (L.) Körb. - on trunks of Acer platanoides, Tilia cordata and Quercus robur, on branches of Populus tremula.

Anisomeridium polypori (Ellis \& Everh.) M. E. Barr - on trunk of Acer platanoides.

Arthonia byssacea (Weigel) Almq. - on trunks of Quercus robur and Fraxinus excelsior; A. radiata (Pers.) Ach. - on trunks of Fraxinus excelsior, on branches of Corylus avellana; $\boldsymbol{A}$. ruana A. Massal. - on trunks of Alnus glutinosa, Quercus robur, Fraxinus excelsior and Acer platanoides, on branches of Corylus avellana; A. spadicea Leight. - on trunks of Alnus glutinosa, A. incana, Quercus robur and Tilia cordata.

\#Athelia arachnoidea (Berk.) Jülich - on thalli of various epiphytic lichens.

Bacidia rubella (Hoffm.) A. Massal. - on trunks of Acer platanoides; B. subincompta (Nyl.) Arnold - on trunks of Acer platanoides and Alnus glutinosa.

Bacidina arnoldiana (Körb.) V. Wirth \& Vězda - on trunks of Alnus glutinosa and Alnus incana; B. inundata (Fr.) Vězda - on seasonally submerged roots of Ulmus sp. by the stream side.

Biatora chrysantha (Zahlbr.) Printzen - on trunk of Tilia cordata; B. ocelliformis (Nyl.) Arnold - on trunk of Fraxinus excelsior.

Biatoridium monasteriense J. Lahm ex Körb. - on epiphytic mosses and bark on trunk base of Acer platanoides.

Buellia griseovirens (Turner \& Borrer ex Sm.) Almb. - on trunks and branches of various deciduous trees.

Calicium glaucellum Ach. - on wood of living trunk of Quercus robur.

Caloplaca citrina (Hoffm.) Th. Fr. - on stone wall.

Candelariella reflexa (Nyl.) Lettau - on trunk of Alnus glutinosa; C. vitellina (Hoffm.) Müll. Arg. - on trunks of Padus avium, Quercus robur and Populus tremula, on siliceous stones; C.xanthostigma (Ach.) Lettau - on trunks and branches of Quercus robur, Acer platanoides and Populus tremula.

Catillaria nigroclavata (Nyl.) Schuler - on trunks of Acer platanoides and Populus tremula.

Cetrelia olivetorum (Nyl.) W. L. Culb. \& C. F. Culb. - on trunk of Tilia cordata, on branches of Corylus avellana and Acer platanoides.

Note. The species is given here as Cetrelia olivetorum s.l., as it was done so far in Lithuania. Studies aiming to reveal composition of the complex are pending. 
Chaenotheca brachypoda (Ach.) Tibell - on snags of Picea abies; Ch. chrysocephala (Turner ex Ach.) Th. Fr. - on trunks of Picea abies; Ch.ferruginea (Turner ex Sm.) Mig. - on trunks of Betula pendula, Pinus sylvestris and Tilia cordata; Ch. furfuracea (L.) Tibell - on roots of upended Picea abies, on wood of Quercus robur in a trunk hollow, on snags and stumps of Picea abies; Ch. phaeocephala (Turner) Th. Fr. - on trunk of Quercus robur; Ch. stemonea (Ach.) Müll. Arg. - on wood of snags, on trunks of Picea abies and Quercus robur; Ch. trichialis (Ach.) Th. Fr. - on trunks of Quercus robur, on snags of Picea abies; Ch. xyloxena Nádv. - on wood of snags.

!+Chaenothecopsis debilis (Sm.) Tibell - on wood of living trunk of Quercus robur; + Ch. pusilla (Ach.) A. F. W. Schmidt - on roots of upended Picea abies.

Chrysothrix candelaris (L.) J. R. Laundon - on trunk of Quercus robur.

Cladonia cenotea (Ach.) Schaer. - on decaying stumps; C. chlorophaea (Flörke ex Sommerf.) Spreng. - on trunk bases of Pinus sylvestris, Quercus robur and Acer platanoides, on decaying wood; C. coniocraea (Flörke) Spreng. - on decaying wood, on trunk bases of various trees; $\boldsymbol{C}$. digitata (L.) Hoffm. - on decaying stumps, on trunk bases of Pinus sylvestris; C. fimbriata (L.) Fr. - on decaying stumps, on trunks of Betula spp. on soil at the forest edge; C. grayi G. Merr. ex Sandst.. - on wood of fallen decaying trunks; C. homosekikaica Nuno - on trunk of Tilia cordata; C. macilenta Hoffm. - on trunks of Betula pendula and Pinus sylvestris; C. ochrochlora Flörke - on decaying wood of fallen trunks, snags and stumps; C. parasitica (Hoffm.) Hoffm. - on stump of Quercus robur.

\#Clypeococcum hypocenomycis D. Hawksw. - on thalli of Hypocenomyce scalaris.

Coenogonium pineti (Ach.) Lücking \& Lumbsch - on trunks of Alnus glutinosa and Pinus sylvestris.

Evernia prunastri (L.) Ach. - on trunks and branches of various trees.

Fellhanera gyrophorica Sérus., Coppins, Diederich \& Scheid. - on trunk of Quercus robur.

Fuscidea pusilla Tønsberg - on trunks of Alnus glutinosa and Betula pendula.

Graphis scripta (L.) Ach. - on trunks of various deciduous trees.

Hypocenomyce scalaris (Ach.) M. Choisy - on decaying stumps and snags, on trunks of Betula pendula and Pinus sylvestris.

Hypogymnia physodes (L.) Nyl. - on trunks and branches of various trees; H. tubulosa (Schaer.) Hav. - on trunks of Tilia cordata.

Hypotrachyna revoluta (Flörke) Hale - on trunk of Alnus glutinosa.

\#Illosporium carneum Fr. - on thallus of Peltigera didactyla.

Imshaugia aleurites (Ach.) S. L. F. Meyer - on trunks of Pinus sylvestris.

Lecania cyrtella (Ach.) Th. Fr. - on trunk of Salix sp.; L. hyalina (Fr.) R. Sant. on trunks of Tilia cordata and Alnus incana; L. naegelii (Hepp) Diederich \& $\mathrm{P}$. Boom - on branches of Tilia cordata.

Lecanora allophana Nyl. - on trunks and branches of Populus tremula, on trunk of Acer platanoides; L. argentata (Ach.) Malme - on trunk of Acer platanoides; $\mathbf{L}$. carpinea (L.) Vain. - on trunks of Tilia spp., Acer platanoides and Alnus glutinosa, on branches of Populus tremula; L. chlarotera Nyl. - on trunks of Acer platanoides, Tilia cordata and Quercus robur, on branches of Populus tremula; L. conizaeoides Nyl. ex Cromb. - on trunks of Pinus sylvestris, on branches of Betula sp.; L. expallens Ach. - on trunks of Quercus robur and Acer platanoides; L. hagenii (Ach.) 
Ach. - on trunk of Quercus robur; L. pulicaris (Pers.) Ach. - on trunks of Padus avium, Quercus robur and Fraxinus excelsior, on branches of Picea abies; L. saligna (Schrad.) Zahlbr. - on snag of Pinus sylvestris; L. symmicta (Ach.) Ach. - on branches of Quercus robur and Betula pendula; L. thysanophora R. C. Harris - on trunks of Tilia cordata and Quercus robur; L. varia (Hoffm.) Ach.- on trunk of Alnus glutinosa, on timber fence.

Lecidea nylanderi (Anzi) Th.Fr. - on trunks of Picea abies.

Lecidella elaeochroma (Ach.) Choisy - on trunks and branches of various deciduous trees; L. euphorea (Flörke) Hertel - on trunks of Salix sp., Acer platanoides and Populus tremula, on branches of Corylus avellana; L. flavosorediata (Vězda) Hertel \& Leuckert - on trunk of Tilia cordata; L. stigmatea (Ach.) Hertel \& Leuckert - on stone wall; L. subviridis Tønsberg - on trunk of Quercus robur.

Lepraria incana (L.) Ach. - on trunks of Picea abies, Alnus glutinosa, Pinus sylvestris and Betula spp., on decaying wood; L. jackii Tønsberg - on trunk of Pinus sylvestris; L. lobificans Nyl. - on trunks of various deciduous trees.

+Leptorhaphis epidermidis (Ach.) Th. Fr. - on trunk of Betula pendula.

\#Lichenoconium lecanorae (Jaap) D. Hawksw. - on apothecia of Lecanora carpinea; \#L. erodens M. S. Christ. \& D. Hawksw. - on thalli of Melanohalea exasperatula, Ramalina farinacea and Parmelia sulcata; \#L. usneae (Anzi) D. Hawksw. - on thallus of Melanohalea exasperatula.

Lobaria pulmonaria (L.) Hoffm. - on trunks of Acer platanoides and Tilia cordata.

\#Marchandiomyces aurantiacus (Lasch) Diederich \& Etayo - on thalli of Physcia tenella, Physcia stellaris, Xanthoria parietina and X. polycarpa.

Melanelixia fuliginosa (Fr. ex Duby) O. Blanco et al. - on trunks of Alnus glutinosa, Acer platanoides and Tilia cordata; M. subargentifera (Nyl.) O. Blanco et al. - on trunk of Tilia cordata; M. subaurifera (Nyl.) O. Blanco et al. - on branches of Picea abies, on trunk of Acer platanoides.

Melanohalea exasperatula (Nyl.) O. Blanco et al. - on trunks and branches of various trees.

Micarea denigrata (Fr.) Hedl. - on timber fence; M. hedlundii Coppins - on decaying stump of Quercus robur; M. melaena (Nyl.) Hedl. - on trunks of Pinus sylvestris; M. micrococca (Körb.) Gams ex Coppins - on decaying stumps, on trunks of Populus tremula and Pinus sylvestris; M. misella (Nyl.) Hedl. - on decaying stumps and wood of fallen trees; M. prasina Fr. - on wood of fallen trees, on trunks of Tilia cordata, Pinus sylvestris, Alnus glutinosa and Acer platanoides.

+Microcalicium ahlneri Tibell - on soft decaying wood in a hollow of Quercus robur trunk. \#M. disseminatum (Ach.) Vain. - on trunks of Quercus robur, apparently on dead thalli of Chaenotheca spp.

Mycoblastus fucatus (Stirt.) Zahlbr. - on trunks of Betula pendula, on twigs of Picea abies.

+Mycocalicium subtile (Pers.) Szatala - on snag of Pinus sylvestris.

\#Nectriopsis parmeliae (Berk \& M. A. Curtis) M. S. Cole \& D. Hawksw. - on primary squamules of Cladonia sp.

Nephroma parile (Ach.) Ach. - on epiphytic mosses on trunk of old Acer platanoides.

Ochrolechia androgyna (Hoffm.) Arnold s.l.- on trunks of Populus tremula and Quercus robur. 
Note. Detailed discussion on Ochrolechia genus in Lithuania see in Kukwa (2009).

Ochrolechia microstictoides Räsänen - on trunks of Quercus robur.

Opegrapha rufescens Pers. - on trunks of Acer platanoides and Fraxinus excelsior;

O. varia Pers. - on trunks of Acer platanoides, Quercus robur and Ulmus sp.

Parmelia submontana Nádv. ex Hale - on branches of Corylus avellana; $\boldsymbol{P}$. sulcata Taylor - on trunks and branches of various trees.

Parmelina tiliacea (Hoffm.) Hale - on branches of Quercus robur and Populus tremula, on trunks of Tilia spp.

Parmeliopsis ambigua (Wulfen) Nyl. - on trunks of Betula pendula, Pinus sylvestris and Alnus glutinosa.

Peltigera didactyla (With.) J. R. Laundon - on soil at forest edges and road scarps, on mosses growing on stone wall; P. praetextata (Flörke ex Sommerf.) Zopf - on soil at the forest edge, on bases of deciduous trees, on moss-covered fallen trees and stumps; P. rufescens (Weiss) Humb. - on soil at the edge of Pinus sylvestris stand.

Pertusaria albescens (Huds.) M. Choisy et Werner - on trunks of various deciduous trees; P. amara (Ach.) Nyl. - on trunks of various deciduous trees; $\boldsymbol{P}$. coccodes (Ach.) Nyl. - on trunks of Tilia cordata, Acer platanoides and Populus tremula; P. leioplaca DC. - on trunks of Fraxinus excelsior and Tilia cordata, on branches of Corylus avellana.

Phaeophyscia endophoenicea (Harm.) Moberg - on trunk of Acer platanoides; Ph. orbicularis (Neck.) Moberg - on trunks and branches of various deciduous trees, on concrete.

Phlyctis agelaea (Ach.) Flot. - on trunks of Acer platanoides; Ph. argena (Spreng.) Flot. - on trunks of various trees.

\#Phoma cytospora (Vouaux) D. Hawksw. - on thallus of Hypogymnia physodes.

Physcia adscendens H. Olivier - on trunks and branches of various deciduous trees; Ph. stellaris (L.) Nyl. - on branches of various deciduous trees; Ph. tenella (Scop.) DC. - on trunks and branches of various deciduous trees.

Physconia distorta (With.) J. R. Laundon - on trunks of Acer platanoides, on branches of Populus tremula; Ph. enteroxantha (Nyl.) Poelt - on trunks of Tilia spp. and Alnus glutinosa, on mosses growing on stone wall; Ph. perisidiosa (Erichsen) Moberg - on trunks of Quercus robur, Acer platanoides and Salix spp.

Placynthiella icmalea (Ach.) Coppins \& P. James - on decaying stumps and wood of fallen trees.

Platismatia glauca (L.) W. L. Culb. \& C. F. Culb. - on branches of various trees.

Pleurosticta acetabulum (Neck.) Elix \& Lumbsch - on trunks of Acer platanoides.

Protoparmeliopsis muralis (Schreb.) M. Choisy - on siliceous stones.

Pseudevernia furfuracea (L.) Zopf - on trunks and branches of various trees.

Pseudosagedia aenea (Wallr.) Hafellner \& Kalb - on trunks of Populus tremula and Fraxinus excelsior.

Pyrenula nitidella (Flörke ex Schaer.) Müll. Arg. - on trunk of Acer platanoides.

Ramalina baltica Lettau - on trunks of Acer platanoides and Quercus robur; $\boldsymbol{R}$. farina$\boldsymbol{c e a}$ (L.) Ach. - on trunks of various trees; R. fastigiata (Pers.) Ach. - on trunks of Acer platanoides and Quercus robur, on branches of Populus tremula; $\boldsymbol{R}$. fraxinea (L.) Ach. - on branches of Populus tremula. 
Reichlingia leopoldii Diederich \& Scheid. - on trunks of Tilia cordata and Quercus robur.

Rinodina pyrina (Ach.) Arnold - on branches of Tilia cordata.

Rinodina exigua (Ach.) Gray - on trunk of Acer platanoides.

Ropalospora viridis (Tønsberg) Tønsberg - on trunks of Acer platanoides, Quercus robur, Padus avium, Populus tremula, Alnus glutinosa and Betula spp., on branches of Corylus avellana.

\#Roseliniella cladoniae (Anzi) Matzer \& Hafellner - on thallus of Cladonia chlorophaea.

Scoliciosporum umbrinum (Ach.) Arnold - on a siliceous stone.

Strangospora moriformis (Ach.) Stein - on timber fence.

\#Syzygospora physciacearum Diederich - on thallus of Physcia stellaris.

\#Taeniolella beschiana Diederich - on thallus of Cladonia chlorophaea.

!Thelenella pertusariella (Nyl.) Vain. - on base of old Lonicera xylosteum branches, on branches of Corylus avellana.

Trapelia placodioides Coppins et P. James - on a siliceous stone.

Trapeliopsis flexuosa (Fr.) Coppins \& P. James - on various decaying wood; T. granulosa (Hoffm.) Lumbsch - on decaying stumps, on trunks of Pinus sylvestris.

\#Tremella cladoniae Diederich et M.S.Christ. - on thalli of Cladonia coniocraea; \#T. lichenicola Diederich - on thalli of Mycoblastus fucatus.

Tuckermanopsis chlorophylla (Willd.) Hale - on trunk of Tilia cordata .

Usnea subfloridana Stirt. - on branches of Tilia cordata.

Verrucaria dolosa Hepp - on calcareous pebbles; V. hydrela Ach. - on siliceous stones in a stream bed, on seasonally submerged roots of Ulmus sp. by the stream side; V. muralis Ach. - on calcareous pebbles; V. nigrescens Pers. - on stone wall; V. praetermissa (Trevis.) Anzi - on siliceous stones in a stream bed.

Vezdaea aestivalis (Ohlert) Tscherm.-Woess \& Poelt - on epiphytic mosses on trunks of Tilia cordata and Acer platanoides.

Xanthoparmelia conspersa (Ach.) Hale - on siliceous stones; X. stenophylla (Ach.) Hale - on siliceous stones.

Xanthoria parietina (L.) Th. Fr. - on trunks and branches of various deciduous trees, on concrete; $\boldsymbol{X}$. polycarpa (Hoffm.) Th. Fr. ex Rieber - on branches, rarely on trunks of various deciduous trees.

\#Xanthoriicola physciae (Kalchbr.) D. Hawksw. - on thallus and apothecia of Xanthoria parietina.

\section{PAVILNIAI REGIONAL PARK}

Absconditella lignicola Vězda et Pišut - on wood of decaying fallen Picea abies trunk.

Amandinea punctata (Hoffm.) Coppins et Scheid. - on trunks of Tilia cordata and Acer platanoides.

Anisomeridium polypori (Ellis et Everh.) M. E. Barr - on trunks of Acer platanoides and Ulmus sp. 
Arthonia byssacea (Weigel) Almq. - on trunk of Acer platanoides; A. ruana A. Massal. - on trunks of Ulmus sp. and Alnus incana.

\# Athelia arachnoidea (Berk.) Jülich - on thalli of various epiphytic lichens.

Bacidia brandii Coppins \& P. Boom - on twigs of Vaccinium myrtillus; !Bacidia caligans (Nyl.) A. L. Sm. - on branches of old Sambucus racemosa.

Bacidina arnoldiana (Körb.) V. Wirth \& Vězda - on decaying wood of fallen trees, on trunks of Ulmus sp. and Alnus incana.

"Biatora" sp. - on branches of old Sambucus racemosa, on trunks of Ulmus sp., Alnus incana and Acer platanoides.

Note. this sterile sorediate species lacking any secondary metabolites was tentatively ascribed to Biatora genus (for further notes on "Biatora" sp. see Motiejūnaitè (2007b), Motiejūnaitė and Jucevičienè (2005)).

Buellia badia (Fr.) A. Massal. - on a siliceous stone; B. griseovirens (Turner \& Borrer ex Sm.) Almb. - on branches of Corylus avellana and Quercus robur, on trunks of Tilia cordata and Populus tremula, on wood of decaying fallen trunk of Picea abies.

Calicium viride Pers. - on trunks of Quercus robur.

Caloplaca saxicola (Hoffm.) Nordin - on stone wall.

Candelariella reflexa (Nyl.) Lettau - on trunks of Populus tremula; C. vitellina (Hoffm.) Müll. Arg. - on a siliceous stone; C. xanthostigma (Ach.) Lettau - on trunks of Quercus robur and Ulmus sp.

Chaenotheca brachypoda (Ach.) Tibell - on wood of Acer platanoides in trunk hollow; Ch. chrysocephala (Turner ex Ach.) Th. Fr. - on trunk of Tilia cordata; Ch. ferruginea (Turner ex Sm.) Mig. - on trunks of Quercus robur, Picea abies and Pinus sylvestris; Ch. phaeocephala (Turner) Th. Fr. - on trunks of Quercus robur; $\boldsymbol{C h}$. stemonea (Ach.) Müll. Arg. - on trunks of Picea abies; Ch. trichialis (Ach.) Th. Fr. - on trunks of Quercus robur and Acer platanoides.

Cladonia coniocraea (Flörke) Spreng. - on bases of various deciduous trees, on decaying wood of stumps and fallen trees; $\boldsymbol{C}$. fimbriata (L.) Fr. - on bases of various deciduous trees, on decaying wood of stumps and fallen trees; $\boldsymbol{C}$. furcata (Huds.) Schrader - on soil at the edge of pine stand; $\boldsymbol{C}$. homosekikaica Nuno - on stump of Picea abies; $\boldsymbol{C}$. macilenta Hoffm. - on decaying stumps.

\#Clypeococcum hypocenomycis D. Hawksw. - on thalli of Hypocenomyce scalaris.

Coenogonium pineti (Ach.) Lücking \& Lumbsch - on trunks of Quercus robur and Picea abies.

Evernia prunastri (L.) Ach. - on trunks and branches of Quercus robur and Tilia cordata.

Fuscidea pusilla Tønsberg - on trunks of Populus tremula.

Graphis scripta (L.) Ach. - on trunks of Ulmus sp., Alnus incana and Quercus robur. Hypocenomyce scalaris (Ach.) M. Choisy - on trunks of Picea abies, Pinus sylvestris, Quercus robur and Betula pendula.

Hypogymnia physodes (L.) Nyl. - on trunks and branches of various trees; H. tubulosa (Schaer.) Hav. - on trunks of Betula pendula.

\#Illosporiopsis christiansenii (B. L. Brady \& D. Hawksw.) D. Hawksw. - on thalli of Physcia tenella. 
Lecania cyrtella (Ach.) Th. Fr. - on branches of Corylus avellana, Quercus robur and Sambucus racemosa; L. naegelii (Hepp) Diederich \& P. Boom - on branches of Sambucus racemosa.

Lecanora carpinea (L.) Vain. - on trunks of Quercus robur and Acer platanoides; $\boldsymbol{L}$. chlarotera Nyl. - on trunks of Quercus robur and Acer platanoides; L. conizaeoides Nyl. ex Cromb. - on trunks of Picea abies and Betula pendula; L. expallens Ach. on trunks of Quercus robur and Tilia cordata; L. hagenii (Ach.) Ach. - on branches of Fraxinus excelsior; L. polytropa (Ehrh. ex Hoffm.) Rabenh. - on a siliceous stone; L. pulicaris (Pers.) Ach. - on trunks of Picea abies and Alnus incana, on branches of Alnus incana and Tilia cordata; L. symmicta (Ach.) Ach. - on trunks of Quercus robur and Acer platanoides.

Lecidella elaeochroma (Ach.) Choisy - on trunks and branches of various deciduous trees.

Lepraria incana (L.) Ach. - on trunks of various trees; L. lobificans Nyl. - on trunks of Ulmus sp.

+Leptorhaphis epidermidis (Ach.) Th. Fr. - on trunk of Betula pendula.

\#Lichenoconium erodens M. S. Christ. \& D. Hawksw. - on thalli of Hypogymnia physodes.

\#Marchandiomyces aurantiacus (Lasch) Diederich \& Etayo - on thalli of Physcia tenella, Xanthoria parietina and X. polycarpa.

Melanohalea exasperatula (Nyl.) O. Blanco et al. - on branches of Quercus robur, Corylus avellana, Malus domestica and Picea abies.

Melanelixia fuliginosa (Fr. ex Duby) O. Blanco et al. - on branches of Corylus avella$n a$, on trunks of Tilia cordata, Alnus incana, Acer platanoides and Quercus robur.

Micarea prasina Fr. - on wood of decaying fallen trees.

Mycoblastus fucatus (Stirt.) Zahlbr. - on branches of Corylus avellana.

+ Mycocalicium subtile (Pers.) Szatala - on snag of Picea abies.

Parmelia sulcata Taylor - on trunks and branches of various deciduous trees, on siliceous stones.

Parmelina tiliacea (Hoffm.) Hale - on trunks of Tilia cordata, Quercus robur and Acer platanoides, on branches of Malus domestica and Quercus robur.

Parmeliopsis ambigua (Wulfen) Nyl. - on trunks of Betula pendula.

Peltigera praetextata (Flörke ex Sommerf.) Zopf - on decaying fallen tree, laying in a stream bed.

Pertusaria albescens (Huds.) M.Choisy et Werner - on trunks of Quercus robur and Tilia cordata.

Phaeophyscia nigricans (Flörke) Moberg - on trunks of Populus tremula; Ph. orbicularis (Neck.) Moberg - on trunks and branches of various deciduous trees, on siliceous stones.

Phlyctis argena (Spreng.) Flot. - on trunks of various deciduous trees.

Physcia adscendens $\mathrm{H}$. Olivier - on branches of various deciduous trees, on siliceous stones; Ph. caesia (Hoffm.) Fürnr. - on a siliceous stone; Ph.stellaris (L.) Nyl. - on branches of Corylus avellana, Malus domestica, Alnus incana and Fraxinus excelsior; Ph. tenella (Scop.) DC. - on branches of various deciduous trees, on siliceous stones.

Physconia enteroxantha (Nyl.) Poelt - on trunks of Tilia cordata and Alnus incana. 
Placynthiella icmalea (Ach.) Coppins \& P.James - on decaying wood of stumps and fallen trees.

Platismatia glauca (L.) W. L. Culb. \& C. F. Culb. - on branches of Picea abies.

Porpidia crustulata (Ach.) Hertel \& Knoph - on a siliceous stone.

Protoparmeliopsis muralis (Schreb.) M. Choisy - on a siliceous stone.

Pseudevernia furfuracea (L.) Zopf - on branches of Alnus incana, Quercus robur and Picea abies.

Pseudosagedia aenea (Wallr.) Hafellner \& Kalb - on trunk of Alnus incana.

+Pycnidiella resinae (Ehrenb.) Höhn. - on resinous exudates of Picea abies.

Ramalina farinacea (L.) Ach. - on trunks of Quercus robur; R. fastigiata (Pers.) Ach. - on trunks of Alnus incana; R. fraxinea (L.) Ach. - on trunks of Quercus robur and Ulmus sp.

Reichlingia leopoldii Diederich \& Scheid. - on trunk of Quercus robur.

Ropalospora viridis (Tønsberg) Tønsberg - on trunks of Alnus incana and Quercus robur.

+Stenocybe pullatula (Ach.) Stein - on trunks of Alnus incana.

Trapeliopsis granulosa (Hoffm.) Lumbsch - on decaying wood of stumps and fallen trees.

Tuckermanopsis chlorophylla (Willd.) Hale - on branches of Picea abies.

Verrucaria hydrela Ach. - on siliceous stomes in a stream bed; V. praetermissa (Trevis.) Anzi - on siliceous stones in a stream bed.

Vulpicida pinastri (Scop.) J.-E.Mattsson \& M. J. Lai - on trunks of Quercus robur and Betula pendula.

Xanthoparmelia conspersa (Ach.) Hale - on a siliceous stone.

Xanthoria parietina (L.) Th. Fr. - on trunks and branches of various deciduous trees; $X$. polycarpa (Hoffm.) Th. Fr. ex Rieber - on branches of various deciduous trees.

\section{RESULTS AND DISCUSSION}

Altogether 172 species of lichens and allied fungi were recorded in Verkiai RP and 92 species in Pavilniai RP. Three lichen species - Absconditella pauxilla, Thelenella pertusariella (from Verkiai RP), Bacidia caligans (from Pavilniai RP) and one saprobic fungus - Chaenothecopsis debilis (in Verkiai RP) were recorded for the first time in Lithuania.

Absconditella pauxilla is a rare species, so far mainly reported from western Europe, also known from Sweden (Santesson et al. 2004), Czech Republic (Palice 1999) and northern Poland (Czarnota, Kukwa 2008). Apparently it is mainly confined to dead bryophytes and more rarely to wood in humid situations. Present find in Lithuania confirms ecological requirements of this species earlier mentioned by other authors: the lichen inhabited patch of dead mosses growing on the lake shore.

Thelenella pertusariella is another rarely collected species, previously thought to be arctic-alpine. It is characterised by corticolous habit, pale, immersed perithecia, submuriform ascospores and asci with unthickened apex. In Eurasia it is known so 
far from Austrian Alps (Mayrhofer 1987), Fennoscandia - Sweden, Norway and Finland (Santesson et al. 2004), Russia (Novgorod and Murmansk regions, northern Urals and western Siberia) (Kataeva et al. 2005), Latvia (Piterāns 1982) and Germany (Cezanne, Eichler 2002). The ecology of the lichen in temperate lowlands is little known, but apparently it favours shady humid habitats in old forests (e.g. description in Cezanne, Eichler 2002). T. pertusariella is doubtfully separated from a similar species Thelenella vezdae (H. Mayrhofer et Poelt) Coppins et Fryday which differs in half-immersed to sessile perithecia, thin, richly branched and anastomosing paraphysoids, asci with thickened apex and predominantly lignicolous habit (Mayrhofer, Poelt 1985). Recently, however, it is discussed that both taxa might be conspecific (Cezanne, Eichler 2002; Palice 1999).

Bacidia caligans is being reported during the last 20 years with increasing frequency: it was found in a number of countries of northern, central and southern Europe. Very often it is recorded from anthropogenic substrates or habitats under strong anthropogenic influence, e. g. trees and shrubs in cities and towns (Aptroot et al. 2005; Diederich 1989; Kowalewska, Kukwa 2003), stone buildings and urban wasteland (Coppins 1992; Gilbert 1990; Larsen 1995), therefore it is quite possible to assume that the lichen is spreading recently. In our case $B$. caligans was found on branches of Sambucus racemosa in a suburban forest with low lichen diversity, apparently influenced by transport and industrial emissions of the city.

Chaenothecopsis debilis is a widely distributed saprobic calicioid fungus found on lignum of various trees (Tibell 1999). Of all species of the genus, which were recorded in Lithuania, it is distinguished mainly by chemical reactions with $\mathrm{K}$ and $\mathrm{HNO}_{3}$. C. debilis apparently is not common in Lithuania, as it becomes more rare southwards of the boreal zone and, though not uncommon in Fenoscandia, it was recorded only in few countries of Central and Southern Europe (Tibell 1999; Titov 2006 and literature cited therein).

During the present study 7 lichen species of Lithuanian Red Data Book (LRDB) were registered (all only in Verkiai RP) (Tab. 1): 2 species of category 1 (E): Nephroma parile (1 locality), Cladonia parasitica (1 locality); 3 species of category 2 (V): Cetrelia olivetorum (2 localities), Lobaria pulmonaria (2 localities), Phaeophyscia endophoenicea (1 locality) and 2 species of category 3 (R): Hypotrachyna revoluta (1 locality), Ramalina baltica (2 localities). Almost all their localities (except Cladonia parasitica, one locality of Cetrelia olivetorum and one locality of Ramalina baltica) were situated in Žalieji ežerai Landscape Preserve where fragments of old hardwood and hardwood-spruce forests are still present. A decade earlier three more LRDB species were found in Verkiai RP, which where not registered during present study, maybe overlooked: Arthonia didyma Körb, Chaenotheca chlorella (Ach.) Müll. Arg. and Lecanora albella (Pers.) Ach. (Motiejūnaitè 1999, 2007a).

Table 1

Data of diversity of lichens and allied fungi in Verkiai and Pavilniai Regional Parks

\begin{tabular}{|l|c|c|c|}
\hline \multicolumn{1}{|c|}{ Regional Park } & $\begin{array}{c}\text { Total number } \\
\text { of species }\end{array}$ & $\begin{array}{c}\text { Number of } \\
\text { LRDB species }\end{array}$ & $\begin{array}{c}\text { Number of indicators of Biologically } \\
\text { valuable species (excluding LRDB species) }\end{array}$ \\
\hline Verkiai RP & 172 & 7 & 16 \\
\hline Pavilniai RP & 92 & - & 4 \\
\hline
\end{tabular}


16 species of lichens, indicators of biologically rich forests (Andersson et al. 2002; Motiejūnaité et al. 2004) were registered, meanwhile only four indicators were found in Pavilniai RP (Tab. 1). Notably, the latter park not only bore lower numbers of rare and vulnerable species, but their abundance was visibly lower than in Verkiai RP: e.g., Arthonia byssacea was common in Verkiai RP, meanwhile in Pavilniai it was found only on one phorophyte; Pseudosagedia aenea and Chaenotheca brachypoda were also quite common in Verkiai RP, but both were found only on one phorophyte every in Pavilniai RP. Chaenotheca phaeocephala, however, was uncommon in both parks.

\section{CONCLUSIONS}

Evaluation of diversity of lichen biota of Verkiai and Pavilniai Regional Parks shows strong differences due to different anthropogenic pressure induced on both territories. Verkiai RP, at least in parts, has still preserved qualities of biocentre of lichens characteristic of old-growth forests, meanwhile Pavilniai RP bear nothing more than common lichen biota of suburban areas. Verkiai RP, especially Žalieji Ežerai Landscape Preserve is still a refugium for several very rare and vulnerable species in Lithuania, such as Nephroma parile and Cladonia parasitica. Vulnerable and rapidly declining lichen Lobaria pulmonaria is still found in large and viable pupulations. The gravest dangers for the habitats of these lichens are transport and related air pollution as well as increasing stress of recreational activities.

Acknowledgements. It is a great pleasure and honour to dedicate this paper to my colleague and longtime friend and co-worker Professor Krystyna Czyżewska with sincere thanks for her kindness and many warm moments shared together in Poland and in Lithuania.

The inventory of lichen biota was financed by the Directorate of Verkiai and Pavilniai Regional Parks. Visit to the Copenhagen University was granted by the EU CORDIS programme SYNTHESYS (DKTAF-1825). I am grateful to Ulrik Søchting for providing possibility to use TLC techniques and to Eric Steen Hansen for help while working at the herbarium (C). Visit to the Botanical Museum Berlin-Dahlem (Freie Universität Berlin) was granted by the EU CORDIS programme SYNTHESYS (DE-TAF-1905), curator of the herbarium Harrie Sipman is cordially thanked for the help while working there. 


\section{REFERENCES}

Aptroot A., Czarnota P., Jüriado I., Kocourková J., Kukwa M., Lõhmus P., Palice Z., Randlane T., Saag L., Sérusiaux E., Sipman H., Sparrius L. B., Suija A., Thüs H. 2005. New or interesting lichens and lichenicolous fungi found during the 5th IAL Symposium in Estonia. Folia Crypt. Estonica 41: $13-22$.

Andersson L., Kriukelis R., Čiuplys R. (eds). 2002. Inventory of woodland key habitats. Methodology. Forest Department, Ministry of Environment, Lithuania. County Forestry Board, Östra Götaland, Sweden. Vilnius-Linköping.

Balevičius K. 1992. Lietuvos raudonoji knyga. Lietuvos respublikos aplinkos apsaugos departamentas. Vilnius.

Blanco O., Crespo A., Divakar P. K., Esslinger T. L., Hawkswoerth D. L., Lumbsch H. T. 2004. Melanelixia and Melanohalea, two new genera segregated from Melanelia (Parmeliaceae) based on molecular and morphological data. Mycol. Res. 108: 873-884.

Cezanne R., Eichler M. 2002. Thelenella pertusariella - Erstfund für Deutschland. Herzogia 15: 297-299.

Coppins B. 1992. Three new lichens for Norway. Graphis Scripta 4: 89-90.

Czarnota P., Kukwa M. 2008. Contribution to the knowledge of some poorly known lichens in Poland. I. The genus Absconditella. Folia Crypt. Estonica 44: 1-7.

Diederich P. 1989. Les lichens épiphytiques et leurs champignons lichenicoles (macrolichens exceptes) du Luxembourg. Travaux Scientifiques de Musée National d'Histoire Naturelle de Luxembourg, Ministere des Affairs Culturelles, Luxembourg.

Gilbert O. L. 1990. The lichen flora of urban wasteland. Lichenologist 22: 87-101.

Jundziłł B. S. 1811. Opisanie roślin litewskich według układu Linneusza. Józef Zawadski, Wilno.

Jundziłł J. 1822a. Rośliny skrytopłciowe postrzezone w okolicach Wilna na początku wiosny 1821 roku. Pamiętnik Farmaceutyczny Wilenski 2: 436-437.

Jundziłł J. 1822b. Trzy późniejsze raporta Pana Józefa Jundziłła do fakultetu fizyczno matematycznego w Uniwersytecie Imperatorskim Wileńskim przyslane z podroźy botanicznej po gubernii Wileńskiej. Pamiętnik Farmaceutyczny Wilenski 2: 574-587.

Jundziłł J. 1822c. Dolączamy tu rejestr częsci herbarza roślin skrytopłciowych, znalezionych w okolicach Wilna w r. 1821 i 1822. Pamiętnik Farmaceutyczny Wilenski 2: 653-654.

Kataeva O. A., Makarova I. I., Taran G. S., Tiurin V. N. 2005. Nekotoryje novyje i interesnyje lishainiki dlia Tiumenskoi oblasti i Zapadnoi Sibiri. Novosti Sist. Nizhsh. Rast. 39: 198-202.

Kirstukas M. (ed.) 2004. Lietuvos gamta. Lutute, Kaunas.

Kowalewska A., Kukwa M. 2003. Additions to the Polish lichen flora. Graphis Scripta 14: 11-17.

Kukwa M. 2009. The lichen genus Ochrolechia in the Baltic countries. Folia Crypt. Estonica. 46: 67-74.

Kukwa M., Motiejūnaitė J. 2005. Notes on two lichen species, Haematomma ochroleucum and Lecanora thysanophora, in Lithuania. Bot. Lithuanica 11: 247-249.

Larsen E. 1995. Five lichens new to Denmark. Graphis Scripta 7: 91-93.

Lücking R., Stuart B. L., Lumbsch H. T. 2004. Phylogenetic relationships od Gomphillaceae and Asterothyriaceae: evidence from a combined Bayesian analysis of nuclear and mitochondrial sequences. Mycologia 96: 283-294.

Mayrhofer H., Poelt J. 1985. Die Flechtengattung Microglaena sensu Zahlbruckner in Europa. Herzogia 7: 13-79.

Mayrhofer H. 1987. Monographie der Flechtengattung Thelenella. Bibl. Lichenol. 26: 1-106.

Miądlikowska J., Motiejūnaitė J. 1994. Some species new to Lithuanian lichen flora. Graphis Scripta 6: 95-96.

Motiejūnaite J. 1999. New to Lithuania species of lichens and lichenicolous fungi (mainly from the eastern part of the country). Bot. Lithuanica 5: 363-378.

Motiejūnaitė J. 2002. Lapiškosios ir krūmiškosios kerpès (Ascomycetes lichenisati. Species foliosae et fruticosae). Lietuvos grybai 13(1). Valstiečių laikraštis, Vilnius.

Motiejūnaitė J. 2006: Lichens and allied fungi of Dusetos forest (Sartai regional Park, north-east Lithuania). Bot. Lithuanica 12: 243-252.

Motiejūnaitė J. 2007a. Ascomycota. Aukšliagrybūnai. Kerpès (Ascomycetes lichenisati). (In:) V. Rašomavičius (ed.). Lietuvos raudonoji knyga: 731-789. Lututè, Vilnius.

Motiejūnaitè J. 2007b. Epiphytic lichen community dynamics in deciduous forests around a phosphorus fertiliser factory in Central Lithuania. Environmental Pollution 146: 341-349. 
Motiejūnaitė J., Czyżewska K., Cieśliński S. 2004. Lichens - indicators of old-growth forests in biocenters of Lithuania and NE Poland. Bot. Lithuanica 10: 59-74.

Motiejūnaitė J., Jucevičienė N. 2005. Epidemiology of the fungus Athelia arachnoidea in epiphytic communities of broadleaved forests under strong anthropogenic influence. Ekologija 4: 23-29.

Motiejūnaite J., Miądlikowska J. 1998. Revised list of the genus Peltigera (Lichenized Ascomycotina) and peltigericolous fungi in Lithuania. Acta Mycol. 33 (2): 307-316.

Motiejūnaite J., Prigodina I. 1999. New or rare in Lithuania lichen species. Bot. Lithuanica 5: 379-386.

Mowszowicz J. 1957-1959. Conspectus florae Vilnensis. I, II, III. Łódzkie Tow. Naukowe, Łódź.

Nordin A., Sundin R., Thor G. 1992. Bacidia caligans and Bacidina chloroticula new to Sweden. Graphis Scripta 3: 134-137.

Orange A., James P. W., White F. J. 2001. Microchemical methods for the identification of lichens. British Lichen Society.

Palice Z. 1999. New and noteworthy records of lichens in the Czech Republic. Preslie, Praha 71: 289336.

Piterāns A. 1982. Lishainiki Latvii. Zinatne, Riga.

Santesson R., Moberg R., Nordin A., Tønsberg T., Vitikainen O. 2004. Lichen-forming and lichenicolous fungi of Fennoscandia. Uppsala University, Uppsala.

Tibell L. 1999. Caliciales. (In:) Nordic lichen flora 1: 20-94, Bohuslän ‘5, Uddevalla.

Titov A. N. 2006. Mikokalicijevyje griby (Poriadok Mycocaliciales) Golarktiki. KMK Scientific Press, Moscow.

Veldkamp J. F. 2004. Bilimbia (Lichenes) resurrected. Lichenologist 36: 191-195. 